\title{
Taxon-specific PCR primers to detect two inconspicuous arbuscular mycorrhizal fungi from temperate agricultural grassland
}

Journal Article

Author(s):

Gamper, Hannes; Leuchtmann, Adrian

Publication date:

2007

Permanent link:

https://doi.org/10.3929/ethz-b-000006507

Rights / license:

In Copyright - Non-Commercial Use Permitted

Originally published in:

Mycorrhiza 17(2), https://doi.org/10.1007/s00572-006-0092-3 


\title{
Taxon-specific PCR primers to detect two inconspicuous arbuscular mycorrhizal fungi from temperate agricultural grassland
}

\author{
Hannes Gamper • Adrian Leuchtmann
}

Received: 22 September 2006 / Accepted: 14 November 2006 / Published online: 10 January 2007

(C) Springer-Verlag 2007

\begin{abstract}
Taxon-specific polymerase chain reaction (PCR) primers enable detection of arbuscular mycorrhizal fungi (AMF, Glomeromycota) in plant roots where the fungi lack discriminative morphological and biochemical characters. We designed and validated pairs of new PCR primers targeted to the flanking regions of the variable domain 1 of the nuclear ribosomal large subunit RNA gene to specifically detect Acaulospora paulinae and an undescribed member of the Diversisporaceae. These two fungal taxa, sporulating late in soil-trap cultures and showing small, faintly coloured spores and weakly staining intraradical structures, were frequently found in roots of Trifolium repens from a high-input agricultural grassland. The newly developed PCR primers may thus enable studies on two inconspicuous AMF taxa that appear to have been overlooked in previous molecular AMF community analyses and for which no specific PCR primers have been published.
\end{abstract}

Keywords Acaulospora paulinae - Arbuscular mycorrhizal fungi Diversisporaceae $\cdot$ Nuclear ribosomal large subunit (LSU, 28S) · Trifolium repens (white clover)

H. Gamper • A. Leuchtmann

Institute of Integrative Biology, ETH Zurich,

Universitätstrasse 16,

CH-8092 Zürich, Switzerland

Present address:

H. Gamper $(\bowtie)$

Department of Biology, University of York,

P.O. Box 373, Heslington,

York YO10 5YW, UK

e-mail: hag500@york.ac.uk

\section{Introduction}

At present, molecular approaches are clearly superior to any morphological (Abbott and Robson 1979; Merryweather and Fitter 1998) or biochemical (Jansa et al. 1999; Sakamoto et al. 2004) methods for studying communities of arbuscular mycorrhizal fungi (AMF, Glomeromycota; Schüßler et al. 2001) in plant roots. This is due to a lack of distinctive features shown by AMF taxa below family level and in some cases the inability to stain certain species within host roots (Clapp et al. 2002; Redecker et al. 2003). Morphological species identification of AMF relies mainly on the characteristics of soil-borne spores and is also difficult in environmental samples due to developmental variation or parasitism of spores. Because factors controlling sporulation and morphological differentiation of AMF taxa are poorly understood, and occurrence of taxa in the spore community and in roots do not necessarily coincide, community studies based solely on spores appear to be of little ecological relevance (Clapp et al. 1995; Sanders 2004). This is why a focus on the fungal root colonisation patterns is crucial to expand knowledge of symbiotic interactions and environmental effects on the mycorrhizal symbiosis.

Molecular studies on AMF communities have repeatedly found new DNA sequence types (e.g. Vandenkoornhuyse et al. 2002; Rosendahl and Stukenbrock 2004; Wirsel 2004). These phylogenetically distinct sequences are either evidence for the occurrence of undescribed AMF taxa or highlight poor taxonomic sequence coverage. The present study addresses both of the above issues in describing new tools to specifically target two inconspicuous AMF taxa in environmental root samples. Polymerase chain reaction (PCR) amplification detection with taxon-specific primers is a simple, straightforward approach to assess the occurrence (presence/absence) of particular AMF taxa. It 
contrasts with other more sophisticated molecular techniques to fingerprint whole communities, such as PCRrestriction fragment length polymorphism (Helgason et al. 1998; Vandenkoornhuyse et al. 2002) and PCR-denaturing gradient gel electrophoresis (Kowalchuk et al. 2002). Most previous PCR-based studies have targeted the nuclear ribosomal cistron to investigate $\mathrm{AMF}$ in environmental DNA samples (Clapp et al. 2002; Redecker et al. 2003), although recently a set of nested PCR primers for presumed single copy genes have been developed to analyse the spore community from natural soil (Stukenbrock and Rosendahl 2005a,b). The multicopy nature of ribosomal genes and available sets of universal primers for PCR amplification (e. g. White et al. 1990) have greatly facilitated earlier work aimed at directly detecting AMF species or species groups using either the nuclear ribosomal large subunit (nrLSU) RNA gene (van Tuinen et al. 1998a; Kjøller and Rosendahl 2000; Geue and Hock 2004) or the internal transcribed spacer (ITS) region (Redecker 2000; Millner et al. 2001; Renker et al. 2003).

The objective of this study was to develop and validate specific PCR primers targeted to the nrLSU RNA gene for direct detection of Acaulospora paulinae and an as yet undescribed member of the Diversisporaceae within roots of field-grown plants. We describe the design of primers, specificity tests using recombinant plasmids from singlespore PCR amplicons and multispore DNA extracts from pure fungal cultures, and successful application of the primers on a large number of environmental root-DNA extracts. Partial nrLSU sequences of indigenous AMF taxa from the experimental site served as reference information, besides sequences deposited in public databases.

\section{Materials and methods}

\section{Arbuscular mycorrhizal fungi}

A putatively undescribed Glomus sp. and five other AMF morpho-taxa belonging to the genus Glomus were recovered from trap cultures (Gilmore 1968; Brundrett et al. 1999) of soil from the Swiss-Free air $\mathrm{CO}_{2}$ Enrichment (FACE) experiment [see Zanetti et al. (1996) for a detailed description of the field experiment] and successfully isolated into pure cultures, using either single spores (Glomus sp. isolates 83, 234 and 272) or a single apparently colonised spore of Scutellospora calospora (Nicol. \& Gerd.) Walker \& Sanders (Glomus sp. isolate 410). A. paulinae Blaszkowski was an additional species that abundantly sporulated in 5- to 8-month-old trap cultures and that might have been overlooked in the first spore screenings. Bulk inocula of all pure isolates have been stored in a $4^{\circ} \mathrm{C}$ room at the Institute of Plant Sciences of ETH in Eschikon (ZH) and reference slides with spores and samples of inoculum were sent to the living culture collections of the international culture collection of arbuscular and vesicular-arbuscular mycorrhizal fungi (INVAM) and the international bank of the Glomeromycota (BEG). In addition, samples of the isolates 83 and 272 of Glomus sp. were sent to the Glomeromycota in vitro collection in Belgium (GINCO-BEL). Glomus sp. is a member of the Diversisporaceae and will be formally described as a new species elsewhere. Spores of other indigenous AMF taxa from this field site were used to confirm the specificity of the newly designed oligonucleotide primers in cross-amplification tests. The INVAM isolate AZ420A of G. eburneum Kenn, Stutz \& Morton (voucher W4729) served as reference.

\section{DNA preparation}

PCR templates from single spores were prepared following the procedure described by Jansa et al. (2003). DNA from multiple spores of monospore isolates was extracted using the DNeasy Plant Mini Kit (Qiagen $\mathrm{GmbH}$, Hilden, Germany), which was also used to extract $20 \mathrm{mg}$ of freeze-dried and ball-milled root samples of $T$. repens. Seven root patches of about $10 \mathrm{~cm}$ diameter were taken at least $15 \mathrm{~cm}$ apart from each of six permanent FACE plots and subdivided into four fractions, yielding 28 samples per plot and a total of 168 samples.

Nested PCR amplification from single-spore DNA extracts, vector-cloning and sequencing

In a nested PCR procedure, the universal eukaryote-specific primers ITS3 (White et al. 1990) and NDL22 (van Tuinen et al. 1998b), and then the eukaryote- LR1 (van Tuinen et al. 1998a) and fungus-specific primer FLR2 (Trouvelot et al. 1999) were used to obtain DNA fragments of approximately 700-760 bp length. Reactions were performed in final volumes of 25 and $60 \mu \mathrm{l}$, for the first and second amplification steps, respectively. Both PCR mixtures contained $1 \times$ PCR buffer [supplied by the manufacturer, containing $50 \mathrm{mM} \mathrm{KCl}, 1.5 \mathrm{mM} \mathrm{MgCl}_{2}$ and $10 \mathrm{mM}$ Tris$\mathrm{HCl}(\mathrm{pH} 9.0)$ ], with additional $1 \mathrm{mM} \mathrm{MgCl} 2,0.2 \mathrm{mM}$ of each dNTP, $1 \mu \mathrm{M}$ of each primer (HPLC purified, Microsynth GmbH, Balgach, Switzerland), $0.02 \mathrm{U} / \mu 1$ Taq DNA Polymerase [containing $0.2 \mathrm{mM}$ Tris- $\mathrm{HCl}(\mathrm{pH}$ 7.5), $0.02 \mathrm{mM}$ dithiothreitol, $0.4 \mu \mathrm{M}$ EDTA (Amersham Pharmacia Biotech, Piscataway, NJ, USA)], and $5 \mu \mathrm{l}$ of singlespore DNA extract or $12 \mu \mathrm{l}$ of diluted $(1: 10-1: 1000)$ products from the first PCR. Thermocyclings used an initial denaturation cycle at $94^{\circ} \mathrm{C}(3 \mathrm{~min})$ and 30 cycles with denaturation at $94^{\circ} \mathrm{C}(45 \mathrm{~s})$, annealing at $60^{\circ} \mathrm{C}(55 \mathrm{~s})$, and extension at $72^{\circ} \mathrm{C}(90 \mathrm{~s})$, followed by a final extension at $72^{\circ} \mathrm{C}$ for $10 \mathrm{~min}$ and cooling down to $4^{\circ} \mathrm{C}$. 
PCR amplification products were purified, vector-cloned and sequenced from plasmids following standard procedures (Sambrook et al. 1989) using ABI Prism ${ }^{\circledR}$ BigDye Terminator Cycle Sequencing chemistry (version 1.1) on an automated capillary ABI Prism ${ }^{\circledR} 310$ sequencer (Applied Biosystems, Forster City, CA, USA). Electropherograms were checked and ambiguities corrected using Sequence Navigator PPC (version 1.0.2b3, Applied Biosystems, Forster City, CA, USA) before comparing the sequences with the public database entries via basic local alignment (BLASTn, Altschul et al. 1997) to confirm glomalean origin.

Taxon-specifc nested PCR amplification from crude DNA extracts of environmental root samples

Primer pairs for $A$. paulinae (f6 5'- TAA ATC TCC GAG GTT TCC TTG GC -3', r1 5'- TCA TCT TTC CCT CAC GGT ACT TG -3') and Glomus sp. (f4 5'- TAA ATC TAC CTG GTT CCC AGG TC -3', r2 5'- TGA ACC CAA AAC CCA CCA AAC TG -3') were used in nested PCR amplifications on 168 crude DNA extracts from roots of $T$. repens plants from the field. The nested PCR amplification comprised a first round of amplification with the universal fungal primer pair LR1/FLR2 in a final volume of $25 \mu \mathrm{l}$ as described above and a second, nested amplification with the newly designed specific primer pairs. Mixtures of the second PCR each contained $1 \times$ PCR buffer (specified above), $1 \mathrm{mM} \mathrm{MgCl}_{2}$, $0.12 \mathrm{mM}$ of each dNTP, $0.6 \mu \mathrm{M}$ of each specific primer (HPLC purified, Microsynth $\mathrm{GmbH}$, Balgach, Switzerland), $0.02 \mathrm{U} / \mu \mathrm{l}$ Taq DNA polymerase (specified above), and $2 \mu \mathrm{l}$ of a $1: 10$ to $1: 10,000$ dilution of the first PCR products, depending on the band intensity of the first amplicons on $1.5 \%(\mathrm{w} / \mathrm{v})$ agarose gels. Annealing temperatures were 55 and $65^{\circ} \mathrm{C}$ and cycle numbers 30 and 35 for the PCR of $A$. paulinae and Glomus sp., respectively. All other thermocycling parameters were as in the first round of amplification, except that time for annealing was only $40 \mathrm{~s}$ and time for extension only $70 \mathrm{~s}$.

The specificity of the newly designed primers was verified by vector-cloning the specific PCR products of four root samples per AMF taxon and sequencing at least ten vector-inserts from re-amplification products obtained with the universal vector primers M13f/r following standard procedures.

Phylogenetic positioning of the two target taxa

The newly derived partial nrLSU RNA gene sequences of A. paulinae and Glomus sp. were aligned with reference sequences from public databases of taxonomically identified fungal isolates of all major clades of AMF, using Clustal X (version 1.83, Thompson et al. 1997). Fine adjustments to the alignment were made manually in MacClade (version 4.08, Sinauer Associates, Sunderland, MA, USA) after visual inspection. Ambiguously aligned regions were excluded before evaluation of the appropriate evolutionary model and phylogenetic analyses. The analysed data set comprised 87 sequence taxa and 503 sites of which 205 were parsimony-informative and 238 constant.

Appropriate models of sequence evolution were determined using ModelTest (version 3.7, Posada and Crandall 1998). A variable base and transition, but equal transversion frequency model with variable substitution rates among sites and a proportion of invariable sites $(\operatorname{TrN}+G)$ was selected by hierarchical likelihood ratio tests. In contrast, by use of the Akaike Information Criterion (AIC) a general time reversible sequence evolution model with variable substitution rates among sites $(\mathrm{GTR}+\mathrm{G})$ was favoured. Both sets of best-fit evolutionary model parameters were used for distance neighbour-joining analyses (objective function set to minimum evolution, 10,000 bootstrap pseudo-replicates) using the program Paup*4b10 (Swofford 2003) and Bayesian analyses using the Metropolis-coupled Markov chain Monte Carlo search algorithm as implemented in the program MrBayes (version 3.1, Ronquist and Huelsenbeck 2003). Four Markov chains were run in parallel for 300,000 generations and trees sampled every 100 th generation. Tree samples taken before the $25 \%$ burnin were discarded before calculating posterior probabilities for tree branches. Log-likelihood values and consensus trees from stationary samples of each of two replicate runs were compared to verify convergence to congruent phylogenetic trees. The trees were rooted with an outgroup of three reference sequences of Archaeospora gerdemannii (Rose, Daniels \& Trappe) Morton \& Redecker, which is a species belonging to an ancestral lineage of AMF (Redecker et al. 2000).

\section{Results}

nrLSU sequences and location of taxon-specific primers for A. paulinae and Glomus sp.

Two specific primer pairs f6/r1 for $A$. paulinae and $\mathrm{f} 4 / \mathrm{r} 2$ for Glomus sp. (see Materials and methods) were deduced based on a multiple alignment of newly generated sequences of AMF taxa indigenous to the field site and selected reference sequences of other taxa from public databases. The priming sites were chosen within distinct regions where the majority of sequence haplotypes of the targeted taxon showed identical nucleotide sequences. Primability and stability of priming sites were confirmed as high in PCR simulations using Amplify (version 1.2, Engels 1993) and specificity with respect to all publicly available 
sequences was checked with BLASTn searches (http:// www.ncbi.nlm.nih.gov/). The forward primer f6 was unique for A. paulinae and the reverse primer $\mathrm{r} 2$ was unique for Glomus sp., which enables specific PCR amplification of these two taxa. The annealing sites for the forward primers f4 and f6 lie immediately upstream of the variable domain 1 (D1) and the reverse primers $\mathrm{r} 1$ and $\mathrm{r} 2$ in the region between D1 and D2, nested within the DNA fragment covered by the primer pair LR1/FLR2 (Fig. 1). Therefore, both pairs of newly designed specific primers cover D1, giving rise to PCR amplification products of $255 \mathrm{bp}$ in the case of A. paulinae and $358 \mathrm{bp}$ in the case of Glomus sp. The newly generated partial sequences of the nrLSU RNA gene (LR1-FLR2 fragment) were deposited in GenBank under the accession numbers: AY639263-AY639265, AY639327-AY639328 (A. paulinae), AY639225-AY639241, AY639306, DQ350448-DQ350453 (Glomus sp.), and EF067886-EF067888 (G. eburneum, AZ420A, W4729).

Primer specificity, sensitivity and applicability under field conditions

A three-step approach was used to test amplification ability of primers and to check their specificity. First, recombinant plasmids of the five most common sequence types of each of the two AMF taxa were used to optimise PCR conditions for new primer pairs, then plasmids of other AMF species from the field site were used to test specificity in the presence of a target and nontarget template of known sequence. Secondly, PCR was performed on multispore DNA extracts prepared from single-spore isolates, using a nested (see Materials and methods) and direct PCR amplification approach. Finally, the broader specificity of the new primers was evaluated on crude root DNA extracts from $T$. repens plants sampled in the field.

Amplification tests using recombinant plasmid templates yielded DNA fragments of the expected size for the target taxa only. Testing against nontarget plasmid templates confirmed the absolute specificity of the primer pairs by the absence of any cross-amplification products (data not shown). Additional PCR amplification tests, using multispore-DNA extracts of single spore cultures, confirmed specificity by the absence of cross-amplification with the tested four AMF taxa (data not shown). The primer pair $\mathrm{f} 4 / \mathrm{r} 2$ yielded strong amplification in direct PCR on multispore genomic DNA extracts of the four pure cultures of Glomus sp., making a nested PCR approach superfluous and demonstrating high sensitivity of this primer pair.

A high specificity and sensitivity of the two new primer pairs was confirmed on a large number of DNA extracts from roots sampled in the field. One hundred fifty-five out of 168 DNA extracts (92.3\%) gave visible PCR amplicons on agarose gels after the first fungus-specific amplification with the primer pair LR1/FLR2. Fifty-seven DNA extracts (33.9\%) gave nested amplification products with the primer pair f6/r1 specific for A. paulinae and 39 extracts (23.2\%) with the primer pair $\mathrm{f} 4 / \mathrm{r} 2$ specific for Glomus sp. Figure 2 shows the amplicons from nested PCR amplification of a DNA extract from roots which were apparently simulta-

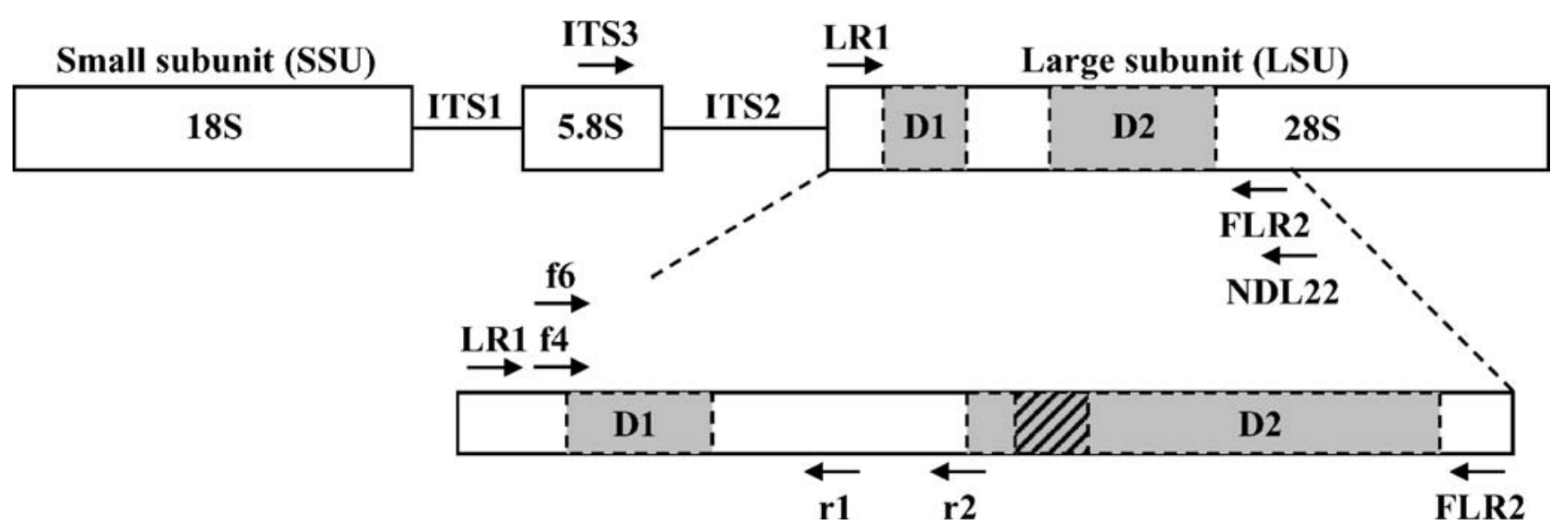

Fig. 1 Schematic representation of the nuclear ribosomal RNA cistron: positions of priming sites at the $5^{\prime}$ end of the nuclear ribosomal large subunit (LSU, 28S) RNA gene. Forward PCR primers are shown above, reverse primers below the gene boxes; arrows indicate the 5'-3'orientation of primers. Fragments of approximately $700-760$ bp are obtained using a nested PCR approaches with primer pairs ITS3/NDL22 (universal eukaryotespecific primers; White et al. 1990; van Tuinen et al. 1998b), and LR1/FLR2 (universal eukaryote- and fungus-specific primer, respec- tively; van Tuinen et al. 1998a; Trouvelot et al. 1999) on single-spore DNA extracts. Nested PCR approaches with crude genomic DNA extracts from environmental root samples and the primer pairs LR1/ FLR2 and f4/r2 for Glomus sp. and f6/r1 for Acaulospora paulinae Blaszkowskid yield DNA fragments of 358 and 255 bp, respectively. The variable domains D1 and D2 are indicated in grey, and the indel, distinguishing members of Glomerales and Diversisporales, is highlighted with black hatching. The diagram is not to scale 


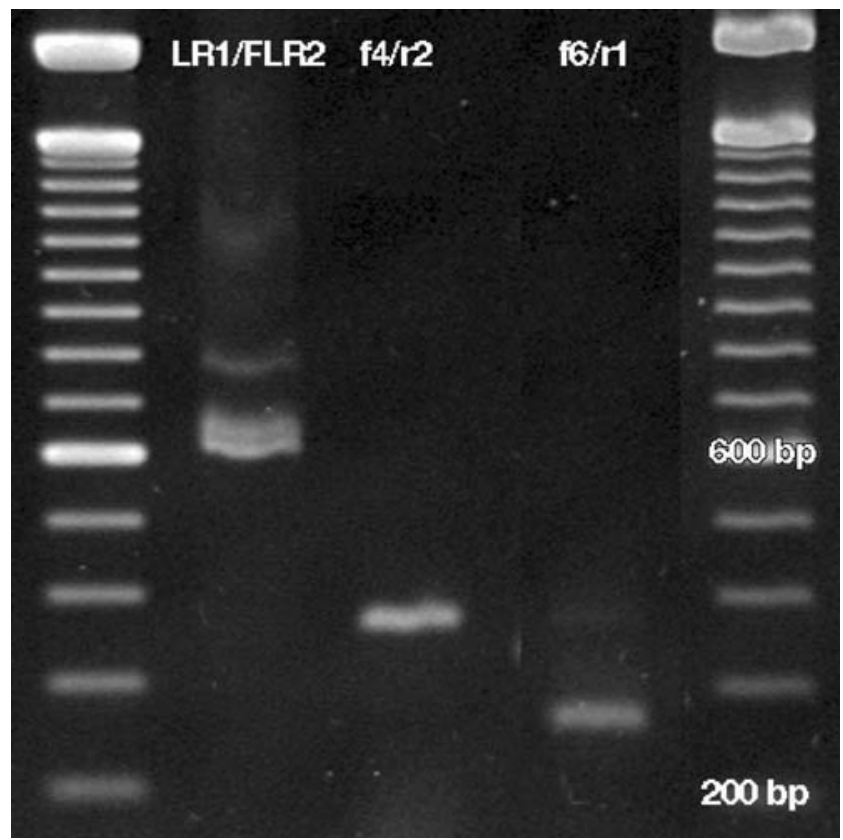

Fig. 2 Example of primer use with a crude genomic DNA extract from environmental root samples of Trifolium repens L.: ethidiumbromide-stained agarose gel $(2 \% \mathrm{w} / \mathrm{v}$ in $1 \times \mathrm{TBE})$ showing PCR products of nested amplifications by the two newly designed taxonspecific PCR primers (indicated above lanes). Lane 1 (primers: LR1/ $F L R 2$ ) contains the products from the first, universal fungus-specific amplification, showing multiple fragments of different length due to the presence of different fungal species. In lane 2 (primers: $f 4 / r 2$, $358 \mathrm{bp}$ ) the specific PCR amplicons from Glomus sp. and in lane 3 (primers: $f 6 / r 1,255 \mathrm{bp}$ ) those from Acaulospora paulinae Blaszkowski are resolved. The negative controls of both amplification reactions contained no products (data not shown)

neously colonised by both AMF taxa. The mean relative frequency of occurrence in the seven sampled root patches per field plot (see Materials and methods) varied between 7.1 and $67.9 \%$ [mean (SEM): $33.9(10.0) \%$ ] for A. paulinae and 0.0 and 46.4\% [mean (SEM): 23.2 (6.9)\%] for Glomus sp. among the six FACE plots.

Sequencing of selected, vector-cloned PCR products confirmed the high specificity of the new PCR primer pairs under field conditions, and showed the presence of sequence variability within the short PCR amplified DNA fragments covering D1 of the nrLSU RNA gene. At least one recovered sequence haplotype was found several times among the sequenced PCR products of the two AMF taxa. Whereas the primer pair $\mathrm{f} 4 / \mathrm{r} 2$ targeted to Glomus sp. showed absolute specificity, the primer pair $\mathrm{f} 6 / \mathrm{r} 1$ targeted to A. paulinae yielded three nonspecific PCR amplicons with an additional band on agarose gels from the 168 analysed root-DNA extracts $(1.8 \%)$. Vector-cloning of two of these PCR amplicons revealed that 18 out of 38 determined sequences $(47.4 \%)$ were of nontarget origin and affiliated with basidiomycetous yeasts.
Phylogenetic position and distinctiveness of $A$. paulinae and Glomus sp.

The phylogenetic position of the two AMF taxa targeted by the newly developed specific primer pairs was evaluated by Bayesian and neighbour joining analyses. Both types of analyses yielded similar results. All sequences derived from single spores of A. paulinae formed a clearly distinct sister clade to A. longula Spain \& Schenck within the family Acaulosporaceae, whereas those from the four singlespore isolates of Glomus sp. clustered in a distinct clade (posterior probability $>0.95$ ), sister to a clade of sequences from the INVAM isolate AZ420A (G. eburneum) both of which are in sister position to the isolate BEG 47 ( $G$. versiforme Daniels \& Trappe), belonging to the Diversisporaceae (Fig. 3, Schüßler et al. 2001).

The clade of Glomus sp. was further structured into four subclades containing sequences derived from up to three different single-spore isolates, pointing at intra-individual polymorphism at the nrLSU RNA gene loci of this fungal taxon. Median pairwise sequence similarity among the 24 Glomus sp. sequences was high (99.1\%) compared with similarities of these sequences to the two public database sequences of G. versiforme BEG 47 (92.4\%) and to three sequences of INVAM isolate AZ420A of G. eburneum (95.9\%). Moreover, 21 nucleotide sites discriminate between Glomus sp. and G. eburneum (AZ420A), which is good evidence for the genetic distinctiveness of these two members of the Diversisporaceae.

All major clades formed by taxa of other AMF families as inferred from reference sequences from public databases were highly resolved. Branch support by posterior probabilities from Bayesian analyses (Fig. 3) was similar to that from nonparametric bootstrap resampling in neighbour joining analyses (data not shown). Moreover, tree topologies were nearly identical in both analyses and remained unchanged with different selected best-fit evolutionary models in Bayesian analyses ( $\mathrm{TrN}+\mathrm{G}$ and GTR $+\mathrm{G}$; see Materials and methods), suggesting that phylogenetic trees based on these partial nrLSU RNA gene sequences were sufficiently robust.

\section{Discussion}

PCR primers were designed to specifically detect for the first time A. paulinae and a currently undescribed AMF taxon Glomus sp. (member of the Diversisporaceae) and validated on DNA extracts from roots of field-grown plants. The primers target the $5^{\prime}$ end of the nrLSU RNA gene, where they flank the variable domain D1. Control PCR confirmed the lack of any cross-amplification in the presence of recombinant plasmids and multispore DNA 


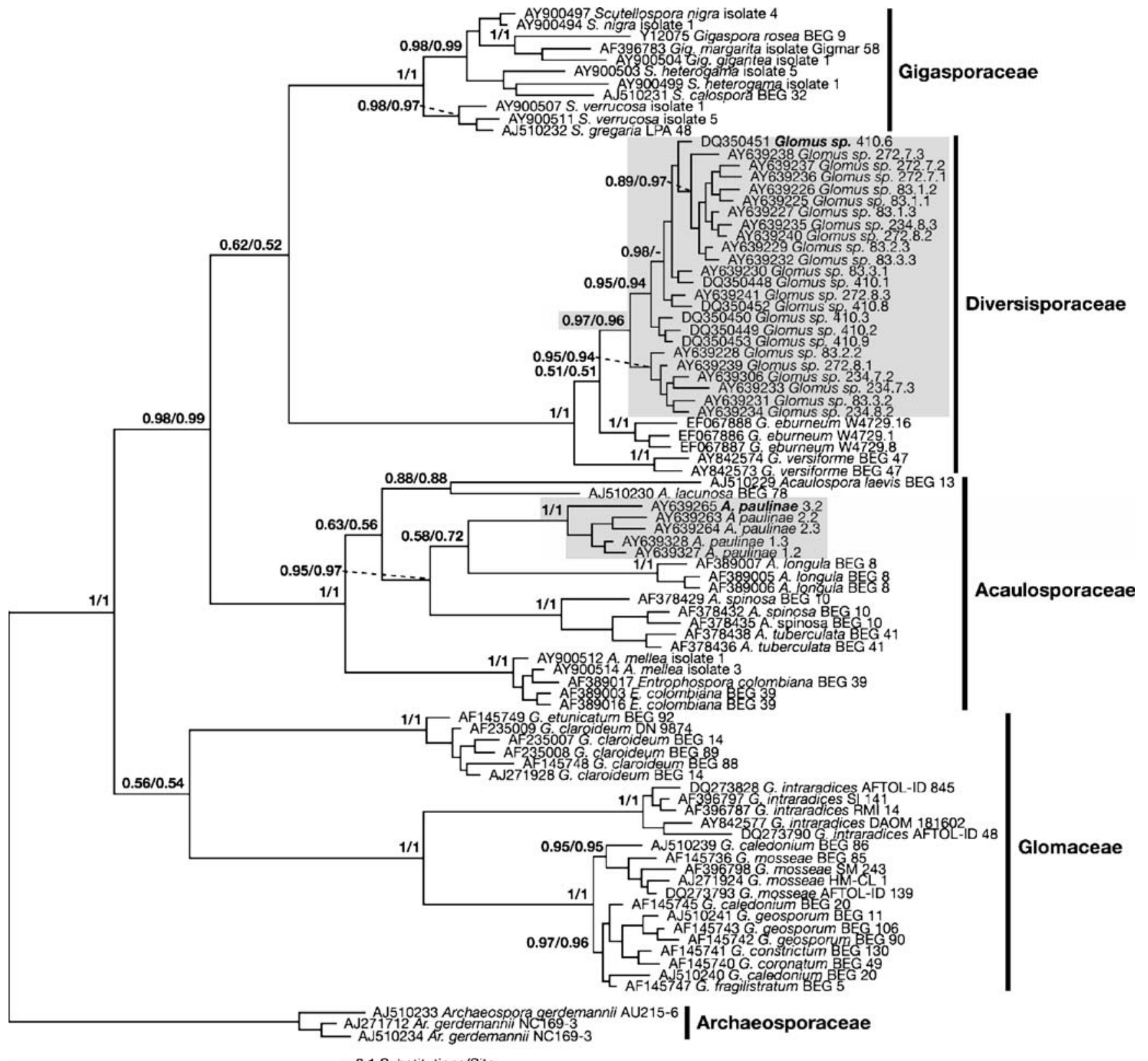

Fig. 3 Rooted phylogenetic consensus tree inferred by Bayesian analysis and based on partial sequences of the nuclear ribosomal large subunit RNA gene (503 unambiguously aligned sites). The clades formed by the two arbuscular mycorrhizal fungi Acaulospora paulinae Blaszkowski and Glomus sp. (Glomeromycota), targeted by the newly developed pairs of specific PCR primers, are highlighted with grey boxes. Sequences were obtained by nested PCR amplification and vector-cloning from single spores of A. paulinae and multispore DNA extracts of four single-spore cultures of Glomus sp.

extracts of a set of other AMF species present at the same field site. Even when applied to a large number of environmental root-DNA extracts the new primers proved to be highly specific with a negligible number of samples $(1.8 \%)$ compromising the specificity of the primer pair $\mathrm{f} 6 /$ r1 for A. paulinae.
Accession numbers of new sequences obtained in this study are suffixed with the spore (or isolate) and clone identifiers. Reference sequences were obtained from public sequence databases and are given with their accession numbers, species names and isolate or strain identifiers. Reference sequences of the basal glomeromycotan taxon Archaeospora gerdemannii (Rose, Daniels \& Trappe) Morton \& Redecker were used as the outgroup. Branch support values of major clades are indicated above branch nodes as the posterior probabilities under the two best-fit evolutionary models $\operatorname{TrN}+\mathrm{G}$ and GTR $+\mathrm{G}$

Although previous studies have already successfully used the $5^{\prime}$ end of the nrLSU RNA gene (van Tuinen et al. 1998a; Kjøller and Rosendahl 2000), discrimination with specific primers in earlier field studies relied on three consecutive PCR reactions employing two pairs of nested primers for a second fungus-specific, and then a third AMF 
taxon-specific, PCR amplification after a first PCR with universal eukaryote-specific primers (Turnau et al. 2001; Jansa et al. 2003). Such double-nested PCR approaches are laborious and bear a high risk of PCR errors and formation of artefacts (Wagner et al. 1994; von Wintzingerode et al. 1997; Speksnijder et al. 2001). The newly developed specific primers described here reliably yielded PCR products from environmental samples in a single nested amplification round reducing, though not completely eliminating, the risk of artefacts.

Besides the ability to directly detect and discriminate among otherwise indistinguishable fungal taxa in roots, a strength of the specific primers is to increase PCR amplification sensitivity compared with amplifications using taxonomically more inclusive primers. A nested PCR approach involving two sets of primers in two steps of amplification is commonly used in AMF research to overcome PCR inhibition and to increase sensitivity for rare DNA templates in the presence of an overwhelming background of nontarget DNA (van Tuinen et al. 1998a). The nested PCR approach developed here involved initial amplification of nrLSU sequence fragments of the whole fungal community and subsequent amplification on the diluted products from the first PCR with taxon-discriminating primers ( $\mathrm{f} 6 / \mathrm{r} 1, \mathrm{f} 4 / \mathrm{r} 2)$.

The primers introduced here were developed on the basis of the most abundant sequence haplotypes of two AMF taxa found at one geographic location. They may, therefore, not cover the entire sequence diversity of these morpho-species present elsewhere. Given the high intraindividual and intra-specific sequence diversity of ribosomal genes in AMF (e.g. Kuhn et al. 2001; Pawlowska and Taylor 2004), the present approach designing taxonspecific primers based on the most frequent sequences appears to be justified and should enable sensitive detection of the most frequent and thus biologically relevant individuals. However, it remains possible that at other field sites the populations of the two AMF taxa consist of different abundant sequence haplotypes, making it necessary to adjust the specific primers. Moreover, the poor taxonomic coverage of the Diversisporaceae by nrLSU sequences in public databases calls for caution regarding the specificity of the primer pair f4/r2. A closer inspection of the binding site of the reverse primer r2 showed only two nucleotide mismatches with those of G. eburneum and G. versiforme, suggesting that together with primer $\mathrm{f} 4 \mathrm{PCR}$ amplification of sequences of these species may also be permitted. However, the use of stringent PCR conditions may avoid co-amplification, as demonstrated here in the intensive screening of environmental root samples.

Using new discriminative PCR primers, it has been possible to track the fate of two fungal taxa, A. paulinae and Glomus sp., that have never been targeted with PCR before and may have been overlooked in previous community studies. The PCR detection of A. paulinae and Glomus $\mathrm{sp}$. in replicate root samples of $T$. repens from a temperate, agricultural grassland in Switzerland indicates that these species occur in high but variable frequency.

Acknowledgements The authors thank Prof. Alex Widmer, Prof. Ian R. Sanders, and Dr. Gerrit Kuhn for their advice on primer design and molecular methods and Dr. Martin Carr, Gracie Barrett, Joanne Leigh and Gemma Atkinson for critical reading of the manuscript. Comments from two anonymous reviewers helped to improve the final version of this manuscript. A research grant from the Swiss Federal Institute of Technology (ETH) Zurich provided financial support for the work carried out during H. Gamper's PhD.

\section{References}

Abbott LK, Robson AD (1979) Quantitative study of the spores and anatomy of mycorrhizas formed by a species of Glomus, with reference to its taxonomy. Aust J Bot 27:363-375

Altschul SF, Madden TL, Schaffer AA, Zhang JH, Zhang Z, Miller W, Lipman DJ (1997) Gapped BLAST and PSI-BLAST: a new generation of protein database search programs. Nucleic Acids Res 25:3389-3402

Brundrett MC, Abbott LK, Jasper DA (1999) Glomalean mycorrhizal fungi from tropical Australia. I. Comparison of the effectiveness and specificity of different isolation procedures. Mycorrhiza 8:305-314

Clapp JP, Young JPW, Merryweather HW, Fitter AH (1995) Diversity of fungal symbionts in arbuscular mycorrhizas from a natural community. New Phytol 130:259-265

Clapp JP, Helgason T, Daniell TJ, Young JPW (2002) Genetic studies of the structure and diversity of arbuscular mycorrhizal fungal communities. In: van der Heijden MGA, Sanders IR (eds) Mycorrhizal ecology. Springer, Berlin Heidelberg New York, pp 201-224

Engels WR (1993) Contributing software to the internet: the Amplify program. Trends Biochem Sci 18:448-450

Geue H, Hock B (2004) Determination of Acaulospora longula and Glomus subgroup Aa in plant roots from grassland using new primers against the large subunit ribosomal DNA. Mycol Res 108:76-83

Gilmore AE (1968) Phycomycetous mycorrhizal organisms collected by open-pot culture methods. Hilgardia 39:87-105

Helgason T, Daniell TJ, Husband R, Fitter AH, Young JPW (1998) Ploughing up the wood-wide web? Nature 394:431

Jansa J, Gryndler M, Matucha M (1999) Comparison of the lipid profiles of arbuscular mycorrhizal (AM) fungi and soil saprophytic fungi. Symbiosis 26:247-264

Jansa J, Mozafar A, Kuhn G, Anken T, Ruh R, Sanders IR, Frossard E (2003) Soil tillage affects the community structure of mycorrhizal fungi in maize roots. Ecol Appl 13:1164-1176

Kjøller R, Rosendahl S (2000) Detection of arbuscular mycorrhizal fungi (Glomales) in roots by nested PCR and SSCP (Single Stranded Conformation Polymorphism). Plant Soil 226:189-196

Kowalchuk GA, de Souza FA, van Veen JA (2002) Community analysis of arbuscular mycorrhizal fungi associated with Ammophila arenaria in Dutch coastal sand dunes. Mol Ecol 11:571-581

Kuhn G, Hijri M, Sanders IR (2001) Evidence for the evolution of multiple genomes in arbuscular mycorrhizal fungi. Nature 414:745-748 
Merryweather J, Fitter A (1998) The arbuscular mycorrhizal fungi of Hyacinthoides non-scripta: I. Diversity of fungal taxa. New Phytol 138:117-129

Millner PD, Mulbry WW, Reynolds SL (2001) Taxon-specific oligonucleotide primers for detection of two ancient endomycorrhizal fungi, Glomus occultum and Glomus brasilianum. FEMS Microbiol Lett 196:165-170

Pawlowska TE, Taylor JW (2004) Organization of genetic variation in individuals of arbuscular mycorrhizal fungi. Nature 427:733-737

Posada D, Crandall KA (1998) Modeltest: testing the model of DNA substitution. Bioinformatics 14:817-818

Redecker D (2000) Specific PGR primers to identify arbuscular mycorrhizal fungi within colonized roots. Mycorrhiza 10:73-80

Redecker D, Morton JB, Bruns TD (2000) Ancestral lineages of arbuscular mycorrhizal fungi (Glomales). Mol Phylogenet Evol $14: 276-284$

Redecker D, Hijri I, Wiemken A (2003) Molecular identification of arbuscular mycorrhizal fungi in roots: perspectives and problems. Folia Geobot 38:113-124

Renker C, Heinrichs J, Kaldorf M, Buscot F (2003) Combining nested PCR and restriction digest of the internal transcribed spacer region to characterize arbuscular mycorrhizal fungi on roots from the field. Mycorrhiza 13:191-198

Ronquist F, Huelsenbeck JP (2003) MrBayes 3: Bayesian phylogenetic inference under mixed models. Bioinformatics 19:1572-1574

Rosendahl S, Stukenbrock EH (2004) Community structure of arbuscular mycorrhizal fungi in undisturbed vegetation revealed by analyses of LSU rDNA sequences. Mol Ecol 13:3179-3186

Sakamoto K, Iijima T, Higuchi R (2004) Use of specific phospholipid fatty acids for identifying and quantifying the external hyphae of the arbuscular mycorrhizal fungus Gigaspora rosea. Soil Biol Biochem 36:1827-1834

Sambrook J, Fritsch EF, Maniatis T (eds) (1989) Molecular cloning. Cold Spring Harbor Laboratory, New York

Sanders IR (2004) Plant and arbuscular mycorrhizal fungal diversity - are we looking at the relevant levels of diversity and are we using the right techniques? New Phytol 164:415-418

Schüßler A, Schwarzott D, Walker C (2001) A new fungal phylum, the Glomeromycota: phylogeny and evolution. Mycol Res 105:1413-1421

Speksnijder A, Kowalchuk GA, de Jong S, Kline E, Stephen JR, Laanbroek HJ (2001) Microvariation artifacts introduced by PCR and cloning of closely related $16 \mathrm{~S}$ rRNA gene sequences. Appl Environ Microbiol 67:469-472

Stukenbrock EH, Rosendahl S (2005a) Clonal diversity and population genetic structure of arbuscular mycorrhizal fungi (Glomus spp.) studied by multilocus genotyping of single spores. Mol Ecol 14:743-752
Stukenbrock EH, Rosendahl S (2005b) Development and amplification of multiple co-dominant genetic markers from single spores of arbuscular mycorrhizal fungi by nested multiplex PCR. Fungal Genet Biol 42:73-80

Swofford DL (2003) PAUP: phylogenetic analysis using parsimony and other methods. Sinauer, Sunderland, MA, USA

Thompson JD, Gibson TJ, Plewniak F, Jeanmougin F, Higgins DG (1997) The ClustalX windows interface: flexible strategies for multiple sequence alignment aided by quality analysis tools. Nucleic Acids Res 25:4876-4882

Trouvelot S, van Tuinen D, Hijri M, Gianinazzi-Pearson V (1999) Visualization of ribosomal DNA loci in spore interphasic nuclei of glomalean fungi by fluorescence in situ hyhridization. Mycorrhiza 8:203-206

Turnau K, Ryszka P, Gianinazzi-Pearson V, van Tuinen D (2001) Identification of arbuscular mycorrhizal fungi in soils and roots of plants colonizing zinc wastes in southern Poland. Mycorrhiza 10:169-174

van Tuinen D, Jacquot E, Zhao B, Gollotte A, Gianinazzi-Pearson V (1998a) Characterization of root colonization profiles by a microcosm community of arbuscular mycorrhizal fungi using 25S rDNA-targeted nested PCR. Mol Ecol 7:879-887

van Tuinen D, Zhao B, Gianinazzi-Person V (1998b) PCR in studies of AM fungi: from primers to application. In: Varma A (ed) Mycorrhiza manual. Springer, Berlin Heidelberg New York, pp 387-399

Vandenkoornhuyse P, Husband R, Daniell TJ, Watson IJ, Duck JM, Fitter AH, Young JPW (2002) Arbuscular mycorrhizal community composition associated with two plant species in a grassland ecosystem. Mol Ecol 11:1555-1564

von Wintzingerode F, Gobel UB, Stackebrandt E (1997) Determination of microbial diversity in environmental samples: pitfalls of PCR-based rRNA analysis. FEMS Microbiol Rev 21:213-229

Wagner A, Blackstone N, Cartwright P, Dick M, Misof B, Snow P, Wagner GP, Bartels J, Murtha M, Penleton J (1994) Point of view: surveys of gene families using polymerase chain reaction: PCR selection and PCR drift. Syst Biol 43:250-261

White TJ, Bruns TD, Lee S, Taylor JW (1990) Amplification and direct sequencing of fungal ribosomal RNA genes for phylogenetics. In: Innes MA, Gelfand DH, Sninsky JJ, White TJ (eds) PCR Protocols: a guide to methods and applications. Academic, New York, pp 315-322

Wirsel SGR (2004) Homogenous stands of a wetland grass harbour diverse consortia of arbuscular mycorrhizal fungi. FEMS Microbiol Ecol 48:129-138

Zanetti S, Hartwig UA, Lüscher A, Hebeisen T, Frehner M, Fischer BU, Hendrey GR, Blum H, Nösberger J (1996) Stimulation of symbiotic N2 fixation in Trifolium repens L. under elevated atmospheric pCO2 in a grassland ecosystem. Plant Physiol 112:575-583 